\title{
EFFECTS OF USING DRIED EGYPTIAN CLOVER AND ORANGE PEELS AS NATURAL FEED ADDITIVES ON EGG PRODUCTION EGG QUALITY AND IMMUNE RESPONSE OF LAYING HENS
}

\author{
Mona S. Ragab and Hanan A. Hassan \\ Poultry Dept., Faculty of Agriculture, Fayoum Univ., Fayoum, Egypt.
}

\begin{abstract}
:
The experimental work of the present study was carried out at the Poultry Research Station, Poultry Department, Faculty of Agriculture, Fayoum University. This experiment was conducted for 11 weeks to study the effect of Egyptian clover dry leaves and orange peels as natural feed additives (NFA) on laying hens. A total number of $108 \mathrm{Hy}$ - Line W- 36 laying hens 49 weeks old were used. The hens were randomly distributed into 9 groups of 12 birds each. Each group was subdivided into 12 replicates (one hen / replicate) and assigned randomly for one of the experimental diets.

The experimental treatments were as follows:-

1 . Hens were fed the basal or control diet (D1).

2. Hens were fed D1+0.2\% Egyptian clover dry leaves (ECL).

3 . Hens were fed D1+0.4\% ECL.

4. Hens were fed D1+0.2\% dry orange peel (OP).

5 . Hens were fed D1+ $0.4 \%$ OP.

6 . Hens were fed D $1+0.2 \% \mathrm{ECL}+0.2 \% \mathrm{OP}$.

7. Hens were fed D1+ $0.2 \% \mathrm{ECL}+0.4 \% \mathrm{OP}$.

8. Hens were fed D $1+0.4 \% \mathrm{ECL}+0.2 \% \mathrm{OP}$.

9. Hens were fed D1+0.4\% ECL+ $0.4 \%$ OP.
\end{abstract}

Results obtained could be summarized in the following:

1- There were insignificant differences among treatments in productive performance except, egg weight (EW). It is clear that laying hens fed diet 8 (containing 0.4 ECL+0.2 OP) had higher $\mathrm{EW}$, whereas, those fed control diet had lower EW during the experimental period ( 49 to 60 weeks of age).

2- No significant differences in egg quality among all dietary treatments except, yolk color, shape index \% and Haugh unit. It is clear that laying hens fed diet 9 (containing 0.4 ECL +0.4 OP) had higher yolk color, hens fed diet 7 (0.2 ECL+0.4 OP) had higher shape index \%, hens fed control diet had higher Haugh unit

3- The results of serum constituents indicated that NFA supplementation significantly affected triglycerides, AST and ALT values.

4- There is insignificant effects on immune response as a result to NFA supplementation was found in laying hen diets throughout the whole experimental period.

5- Hens fed diet 2 (containing 0.20 ECL) gave the best economical and relative efficiency values being 1.429 and $110.6 \%$, respectively followed by hens fed diet 7 (0.2 ECL+ 0.4 OP) (1.345 and $104.1 \%$, respectively), diet 6 (0.2 ECL+ $0.2 \mathrm{OP})$ and than by diet $5(0.4 \mathrm{OP})$, all of which are superior compared to the control diet.

Fayoum J. Agric. Res. \& Dev., Vol. 21, No. 2, July, 2007 
In conclusion, the best performance was seen when $0.20 \mathrm{ECL}$ or $0.2 \mathrm{ECL}+0.4 \mathrm{OP}$ or $0.2 \mathrm{ECL}+0.2 \mathrm{OP}$ were incorporated as feed additives in laying diets as it gave the best economical and relative efficiency values.

Key words: Egyptian clover dry leaves, orange peels, productive performance, serum constituents, immune response, laying hens

\section{INTRODUCTION}

Waste materials from a wide range of agro-industrial processes may be used as the substrates for microbial growth, thereby resulting in upgrading of the waste or the synthesis of valuable by-products. The bulk of the wastes from agriculture or food processing are not suitable for food, a significant proportion (30-70\%) of the dry weight of these wastes are carbohydrates other than cellulose (Forage, 1979).

Citrus juice processing is one of the more important food industries in the world. It produces an enormous quantity of processing residue (Ting and Rouseff, 1983). This constitutes about $50 \%$ of the weight and thus provides an excellent model for the production of value-added products. The peel and other by-products are ultimately dried and marketed as a cattle feed.

Orange peel contains high concentrations of phenols (Manthey, 2004). Its extract contains significant amount of beta-carotene (Ghazi, 1999) and is a good source of vitamin C (Rinzler, 1990). Citrus peel consists of significant antioxidant activity compounds that attributable to minor-occurring flavones (Manthey, 2004 and Anagnostopoulou et al., 2005). Hesperidins, the most important flavanone of orange peel, has antioxidant and diuretic effects in rats (Kroyer, 1986; Galati et al., 1996 and Tirkey et al., 2005). Furthermore, its constituents may counteract enzymatic lipid peroxidation processes (Mtambo et al., 2000).

Ascorbic acid plays a modulating role during stress in guinea pigs (Odumosu, 1982). Also, it has a positive effect on broiler performance raised under hot climate with low mortality (Skrivanova et al., 1999 and AlHomaidan, 2000) and a synergistic antioxidant effect (Mahfouz et al., 1997). Vitamin C or polyphenols increased the antioxidant enzymes in red blood cells (Dragsted et al., 2001). Therefore, it can influence the blood concentration of fibronectin which may be related either directly or indirectly to collagen metabolism (Hsu et al., 1999). Furthermore, it play a role in lowering viral antigenicity and protection as well as enhancement of the immune system of the infected rabbits (Elghaffar et al., 2000).

Flavonoids are plant pigments able to inhibit or kill many bacterial strains, to destroy some pathogenic protozoa and to scavenge free radicals. Yet, their toxicity to animal cells is low. Citrus by-products are rich in Esperidin, Eriocitrin and Narirutin, flavanones with immune modulating properties. A great problem in poultry feeding is the control of animal infections such as coccidiosis, which could be faced by natural products other than drugs.

Hasin et al. (2006) studied the chemical composition of dry orange peel. They found that dry orange peel contained nutrient compounds on dry matter basis; moisture (12.6\%), CP (5.6\%), EE (3.7\%), CF (20.0\%), NFE $(55.1 \%)$, ash $(3.0 \%), \mathrm{Ca}(0.45)$, total phosphorus $(0.30)$ and total xanthophylis $\mathrm{mg} / \mathrm{Kg}$ (83.02).

Fayoum J. Agric. Res. \& Dev., Vol. 21, No. 2, July, 2007 


\section{EFFECTS OF USING DRIED EGYPTIAN CLOVER AND ORANGE.. 190}

The color of egg yolk is very much important for consumers' satisfaction and consumers all over the world usually prefer yolk color ranging from golden yellow to orange, i.e. mid way to high on the Roche Yolk color scale (RYC) as described by Vuilleumiler (1969).

Currently, poultry industry in many countries of the world is facing a problem of desirable egg yolk pigmentation. Many poultry farms could not obtain desirable degree of egg yolk color (Brahmakshatriya and Shrivastava, 1978). The color of egg yolk is produced by carotenoid pigments, specially by xanthophyll which is present in the natural poultry feeds like maize, lucerne, grasses, tomatoes, carrots, algae etc. xanthophyll is also found in marigold and orange skin. Yellow corn, in addition to energy source, also supplies xanthophyll pigment for chicken.

On the basis of the available evidence from quantitative studies, the Animal Nutrition committee on of the National Research Council (1994) has estimated the vitamin A requirements to be 1500 I.U. units $/ \mathrm{kg}$ of diet for growing chickens and 400 I.U. units/kg of diet for laying and breeding hens.

Alfalfa is a readily available, high protein, high fiber feedstuff with one of the slowest rates of passage through the GI system (Garcia et al., 2000). Alfalfa is well balanced in amino acids and rich in vitamins, carotenoids and xanthophylls that give poultry carcasses their desirable yellow color (Ponte $\boldsymbol{e t}$ al., 2004). Alfalfa also contains high levels (2 to $3 \%$ of DM) of saponins, which have been shown to have hypocholesterolemic, anticarcinogenic, antiinflammatory and antioxidant properties (Klita $\boldsymbol{e t} \boldsymbol{a l}$., 1996). Alfalfa is extremely advantageous due to the fermentation properties by cecal microflora that are capable of limiting in vitro growth of Salmonella Typhimurium when alfalfa is present (Donalson et al., 2004 a,b). The chemical composition of alfalfa leaf meal (dry). They found that dry alfalfa leaf meal contained nutrient compounds on dry matter basis; moisture (8.0\%), CP (20.0\%), EE (3.5\%), CF $(21.0 \%)$, NFE $(37.0 \%)$, ash $(10.5 \%)$, Ca (1.45), total phosphorus (0.27), according to U.S. Feed Grain Council (1994).

Therefore, the present experiment was conducted to study the effect of Egyptian clover dry leaves and orange peels as natural feed additives (NFA) on egg production egg quality and immune response of laying hens.

\section{MATERIALS AND METHODS}

The experimental work of the present study was carried out at the Poultry Research Station, Poultry Department, Faculty of Agriculture, Fayoum University from April to July 2003. Chemical analyses were performed in the laboratories of the same department according to the procedures outlined by A.O.A.C. (1990).

A total number of $108 \mathrm{Hy}$ - Line W- 36 laying hens 49 weeks old were reared under the same management conditions in egg production batteries. The hens were randomly distributed into 9 groups of 12 birds each. Each group was subdivided into 12 replicates (one hen / replicate) and assigned randomly for one of the experimental diets. The basal diet was formulated to satisfy nutrient requirements of laying hens according to the strain catalog recommendation $(14.7 \mathrm{CP} \%$ and $2770 \mathrm{ME}, \mathrm{K}$ cal / Kg).

The experimental treatments were as follows:-

1 . Hens were fed the basal or control diet (D1).

2. Hens were fed D1+ 0.2\% Egyptian clover dry leaves (ECL).

3. Hens were fed D1+ $0.4 \%$ ECL.

Fayoum J. Agric. Res. \& Dev., Vol. 21, No. 2, July, 2007 
4. Hens were fed D1+ $0.2 \%$ dry orange peel (OP).

5 . Hens were fed D1+ $0.4 \%$ OP.

6. Hens were fed D $1+0.2 \% \mathrm{ECL}+0.2 \% \mathrm{OP}$.

7. Hens were fed D1+ $0.2 \%$ ECL+ $0.4 \% \mathrm{OP}$.

8. Hens were fed D1+0.4\% ECL $+0.2 \% \mathrm{OP}$.

9. Hens were fed D1+ $0.4 \%$ ECL $+0.4 \%$ OP.

The by-product used in the present trial consisted of the residue from the orange juice industry, then spread on a clean floor for sun drying. After complete dryness, the material was ground and stored until formulating the experimental diets. The composition and chemical analyses of the control diet are shown in Table 1. Artificial light was used beside the normal day light to provide 16-hour day photoperiod. Feed and water were provided ad libitum. The experiment lasted for 11 weeks. Individual body weights were recorded at the beginning and at the end of the study to calculate body weight changes. Egg shape index\% (Carter, 1968) and yolk index \% (Well, 1968) were calculated. Data on egg production (EP), egg weight (EW) and feed intake (FI) were recorded weekly and feed conversion (FC), crude protein conversion (CPC) and caloric conversion ratio (CCR) were calculated. Mortality was recorded daily. No mortality of birds was recorded during the study period. Egg quality measurements were determined monthly on eggs of the last three days. Representative egg samples (12 eggs) from each treatment were collected monthly throughout the experimental period in order to determine egg and shell quality.

Egg shell thickness, including shell membranes, was measured using a micrometer at three locations on the egg (air cell, equator, and sharp end). Haugh unit score was applied from a special chart using egg weight and albumen height which was measured by using a micrometer according to Haugh (1937). The egg yolk visual color score was determined by matching the yolk with one of the 15 bands of the "1961, Roche Improved Yolk Color Fan".

Four hens of each group at 54 weeks of age were injected in wing vein by $0.2 \mathrm{ml}$ of sheep red blood cells solution (SRBCs 9\% suspension), and the blood samples were collected from the wing vein of these birds after one week to determine SRBCs primary immune response. The same birds were reinjected at 60 weeks of age and the blood samples were collected from these birds after 5 days to determine SRBCs secondary immune response in serum and determine the serum constituents. From these birds, blood sample were put in tubes containing heparin to determine the hematological parameters. Packed cell volume, PCV and red and white blood cells counts (WBCs and (RBCs), according to Bauer (1970). Serum constituents were determined commercially using kits, total protein (Weichselbaum, 1946); albumin (Dumas and Biggs, 1972); globulin concentration was calculated as the difference between total protein and albumin; hemoglobin (Wintrobe, 1965); cholesterol (Allain, 1974); triglycerides (Wahlefeld, 1974); aspartate aminotransferase (AST) and alanine aminotransferase (ALT) (Reitman and Frankel, 1957); calcium (Lehman and Henry, 1984); glucose (Howanitz and Howantitz, 1984); phosphorus (Goodwin, 1970).

Antibody response against SRBCs were measured in serum using micro haemagglutination technique as described by Yamamoto and Glick (1982) and Dix and Taylor (1996). The titers were expressed as the log 2 of the reciprocal of the highest dilution giving visible agglutination (Atta et al.,

Fayoum J. Agric. Res. \& Dev., Vol. 21, No. 2, July, 2007 
EFFECTS OF USING DRIED EGYPTIAN CLOVER AND ORANGE.. 192

1998). To determine cutaneous basophil hypersensitivity $(\mathrm{CBH})$ response, three hens from each group were randomly selected at 61 weeks of age and injected with $0.1 \mathrm{ml}$ of phytohaemagglutinin -P (PHA-P) $(100 \mu \mathrm{g} / \mathrm{ml})$ subcutaneously in the right toe web, whereas, $0.1 \mathrm{ml}$ saline was injected subcutaneously in the left toe web which served as the control. The thickness of both toe webs were measured in mm using a micrometer at $24 \mathrm{hr}$ after injection. The CBH response was calculated as described by Atta et al. (1998) as follows: Thickness of right toe web (PHA-P response) / Thickness of left toe web (saline response).

Economical efficiency of egg production was calculated from the input-output analysis which was calculated according to the price of the experimental diets and eggs produced. The values of economical efficiency were calculated as the net revenue per unit of total cost. Analysis of variance was conducted on data obtained according to Steel and Torrie (1980). Significant differences among treatment means were separated using Duncan's multiple range test (Duncan, 1955).

Table 1: Composition and calculated analyses of the control basal diet.

\begin{tabular}{|l|c|}
\hline Items & $\%$ \\
\hline Yellow corn, ground & 69.30 \\
Soybean meal (44\%CP) & 20.00 \\
Calcium carbonate & 8.00 \\
Di calcium phosphate & 2.00 \\
Sodium chloride & 0.30 \\
Vit. and Min. premix * & 0.30 \\
DL - methionine & 0.10 \\
Total & 100.0 \\
Calculated analysis \%** : & \\
CP & 14.75 \\
EE & 2.83 \\
CF & 2.30 \\
Ca & 3.59 \\
Available P & 0.46 \\
Methionine & 0.36 \\
Methionine + Cystine & 0.63 \\
Lysine & 0.77 \\
ME, K cal/Kg & 2771 \\
\hline Cost (L.E./ton) *** & -------- \\
\hline
\end{tabular}

*Each $3.0 \mathrm{Kg}$ of the Vit. and Min. premix manufactured by Agri-Vet Company,

Egypt and contains: Vit. A, 10000000 IU; Vit. D 2000000 IU; Vit. E, 10.0 g; Vit. $\mathrm{K}_{3}, 1.0$ g; Vit. B1, 1.0 g; Vit. B2, 5.0 g; Vit. B6, 1.5 g; Vit. B12, $10.0 \mathrm{mg}$; choline chloride, $250.0 \mathrm{~g}$; biotin, $50.0 \mathrm{mg}$; folic acid, $1.0 \mathrm{~g}$; nicotinic acid, 30.0 g; Ca pantothenate, $10.0 \mathrm{~g}$; Zn, $50.0 \mathrm{~g}$; Cu, $4.0 \mathrm{~g}$; Fe, $30.0 \mathrm{~g}$; Co, $100.0 \mathrm{mg}$; Se, $100.0 \mathrm{mg} ; \mathrm{I}, 300.0 \mathrm{mg}$; $\mathrm{Mn}, 60.0 \mathrm{~g}$, and complete to $3.0 \mathrm{Kg}$ by calcium carbonate.

** According to NRC, 1994.

*** According to market prices of 2003.

Fayoum J. Agric. Res. \& Dev., Vol. 21, No. 2, July, 2007 
Mona S. Ragab and Hanan A. Hassan

RESULTS AND DISCUSSION

Laying hens productive performance:

The effect of treatments on egg production (EP\%), egg mass (EM), egg weight (EW), daily feed intake (FI), feed conversion (FC), crude protein conversion (CPC), caloric conversion ratio (CCR) and live body weight gain (LBWG) are shown in Table 2. There were insignificant differences among treatments in productive performance except, EW. It is clear that laying hens fed diet $8(0.4 \% \mathrm{ECL}+0.2 \mathrm{OP} \%)$ had higher EW, whereas, those fed control diet had lower EW during the experimental period (49 to 60 weeks of age). On the other hand, addition of NFA of the diet significantly $(\mathrm{P} \leq 0.05)$ increased EW. Regarding to egg mass, all of the dietary treatments surpassed the control with the exception of hens fed diets $3(0.4 \%$ ECL) and $5(0.40 \%$ OP) which were lower than the control. Addition of NFA to some diets $2(0.2 \%$ ECL), 6 (0.2\% ECL + 0.2\% OP), 7 (0.2\% ECL+ 0.4\% OP) and diet 9 (0.4\% ECL+ $0.4 \%$ OP) insignificantly improved FC compared to the control.

Results showed that during the experimental period (11 weeks), average LBWG was not significantly affected by any level of the tested materials (Table 2). Concerning the effect of level and type of NFA (Table 2), no significant effects on EP, EM, FI, FC, CPC, CCR and LBWG were observed during all experimental periods studied. Hens fed diet containing $0.8 \%$ (0.4 ECL+0.4 OP) had higher EW value, while, those fed the control diet had lower EW value. In this respect, Hasin et al. (2006) suggested that use of $4 \%$ orange skin in the diet of laying pullets had no significant effect on body weight, EP, EM, EW, FI and FC of experimental birds during 6 weeks of study period. The use of $4 \%$ orange skin in the diet of laying pullet could not affect palatability and therefore feed intake was found to be more or less uniform. The present results on feed consumption agreed well with the results of Khaton et al. (1999) who reported that azolla meal up to $10 \%$ had no effect on the consumption of feed. Results of egg weight disagreed with Sikder et al. (1998) who reported non-significant difference in egg weight from feeding diets containing up to $8 \%$ carrot meal in the layer diet. However, Guclu et al. (2004) reported that any level of alfalfa meal had no effect on EP, EW, FI, FC and LBW. El-Husseiny et al. (2000) found that means of EN and EP were the highest for hens fed $3 \%$ alfalfa. Also, Hashish et al. (1983) indicated that supplementing the diets of laying hens with $400-$ 500 I.U. vitamin $\mathrm{A} / \mathrm{kg}$ increased egg production, improved feed utilization and increased vitamin A content of egg yolk.

\section{External and internal egg quality:}

Results presented in Table (3) indicated no significant differences in egg quality among all dietary treatments including the control group except, yolk color, shape index and Haugh unit. Results also indicated that laying hens fed diet $9(0.4 \%$ ECL $+0.4 \%$ OP) had higher yolk color than those fed the control diet.

Hens fed diet 7 (0.2\% ECL+0.4\% OP) had higher shape index\% being $77.7 \%$ while significant lower values $(\mathrm{P} \leq 0.01)$ were observed for hens fed diet $2(0.2 \%$ ECL). The control group had higher Haugh unit, being $81.03 \%$ while significant lower values $(\mathrm{P} \leq 0.01)$ were observed for hens fed diet $4(0.2 \% \mathrm{OP})$. Yolk index, values revealed insignificant improvement by adding all of the dietary treatments compared to the control group.

Fayoum J. Agric. Res. \& Dev., Vol. 21, No. 2, July, 2007 
EFFECTS OF USING DRIED EGYPTIAN CLOVER AND ORANGE.. 194

Table 2

Fayoum J. Agric. Res. \& Dev., Vol. 21, No. 2, July, 2007 
Table 3

Fayoum J. Agric. Res. \& Dev., Vol. 21, No. 2, July, 2007 


\section{EFFECTS OF USING DRIED EGYPTIAN CLOVER AND ORANGE.. 196}

Concerning the effect of NFA level (Table 3), no significant effect were observed on egg quality during all experimental periods studied were except, yolk color, shape index and Haugh unit. It is clear that laying hens fed diet containing $0.8 \%(0.4 \%$ ECL $+0.4 \%$ OP $)$ had higher yolk color, while, insignificant differences were detected among other treatments were found as compared to the control diet. Laying hens fed diet containing $0.8 \%(0.4 \%$ ECL $+0.4 \%$ OP) had higher shape index value, while, those fed diet containing $0.2 \%$ NFA had lower shape index value. Regarding Haugh unit, value revealed significant reduction by adding any level of NFA to diets compared to the control group. A similar conclusion was reached by Mcdowell $\boldsymbol{e t}$ al. (1990) who found that adding aquatic plants to the diets increased yolk pigmentation while adding $7.5 \%$ of these plants to the diets for laying hens did not adversely affect the egg Haugh units. Hasin et al. (2006) demonstrated no significant effects on external and internal egg qualities except yolk color score. Previous experiments with yellow corn, carrot meal, azolla meal and duck weed meal reported similar trend for both albumen and yolk quality characteristics of eggs (Sikder et al., 1998 and Khaton et al., 1999).

Concerning the effect of type of NFA (Table 3), also no significant effects were detected on egg quality during all experimental periods studied except, yolk color and egg shape index. It is clear that laying hens fed diet containing ECL had higher yolk color and lower egg shape index, while, those fed OP or $(\mathrm{ECL}+\mathrm{OP}) \mathrm{mix}$ had lower yolk color and higher egg shape index.

\section{Physiological traits:}

Serum constituents: Data of serum constituents are summarized in Table 4. The results of serum constituents indicated that NFA supplementation significantly $(\mathrm{P} \leq 0.05$ or $\mathrm{P} \leq 0.01)$ affected triglycerides, AST and ALT values. It can be seen that hens fed control diet had higher serum triglycerides and AST values, while, those fed diet $8(0.4 \% \mathrm{ECL}+0.2 \% \mathrm{OP})$ and $5(0.4 \% \mathrm{OP})$ had lower serum triglycerides and AST, respectively, hens fed diet $6(0.2 \%$ ECL+0.2\% OP) had higher ALT. However, no significant differences were found among dietary treatments for calcium, cholesterol, total protein, albumin, globulin, $\mathrm{A} / \mathrm{G}$ ratio, glucose of serum and phosphorus.

Although total serum cholesterol was not affected by the different experimental treatments, it is difficult to draw conclusions from the data due to large variations in the plasma cholesterol level among experimental hens. Other studies have demonstrated considerable variation in serum cholesterol (El-Husseiny et al., 2000).

Concerning the effect of NFA level (Table 4), it were significant effects $(\mathrm{P} \leq 0.05$ or $\mathrm{P} \leq 0.01)$ on triglycerides, $\mathrm{AST}, \mathrm{ALT}$, total protein and phosphorus values were noted. Regarding to AST values significant reduction was evident by adding any level of NFA to the diets compared to the control group. Laying hens fed diet containing $0.00,0.20,0.80$ and $0.60 \%$ NFA had higher triglycerides, ALT, total protein, and phosphorus values, respectively. While, those fed diet containing $0.60,0.80,0.60$ and $0.00 \%$ NFA had lower triglycerides, ALT, total protein, and phosphorus values.

The results indicated that type of NFA supplementation insignificantly affected all serum constituents studied except triglycerides and phosphorus (Table 4). From this table, it can be observed that hens fed ECL had significantly higher serum triglycerides than those fed $(\mathrm{ECL}+\mathrm{OP})$ mix containing diets, where hens fed (ECL+OP) mix containing diet had significantly higher serum phosphorus.

Fayoum J. Agric. Res. \& Dev., Vol. 21, No. 2, July, 2007 
Table 4

Fayoum J. Agric. Res. \& Dev., Vol. 21, No. 2, July, 2007 


\section{EFFECTS OF USING DRIED EGYPTIAN CLOVER AND ORANGE.. 198}

Immune Responses: Values of total immune response are listed in Table (5). No significant effects on immune response as a result to NFA supplementation was found in laying hen diets throughout the whole experimental period. However, the diet including 0.2\% ECL+ 0.4\% OP (diet 7) supplementation in laying diets showed the best insignificant values in primary immunity response throughout the whole experimental period as compared to the control diet and other experimental groups. Regarding to secondary immunity response all of the dietary treatments surpassed the control, hens fed diet $3(0.4 \%$ ECL) or diet $9(0.4 \%$ ECL $+0.4 \%$ OP) had higher values of secondary immunity response as compared to the control diet, but the difference did not reach significance. Slightly improvement (not significant) in cellular immunity response was found by adding NFA to the diet of laying hens with the exception of diet $2(0.2 \%$ ECL) and $5(0.40 \%$ OP) which was lower than the control. Regarding to hematocrit, red blood cells and white blood cells, it can be noted that hens fed diets 3 (0.4\% ECL), 6 $(0.2 \% \mathrm{ECL}+0.2 \% \mathrm{OP})$ and $8(0.4 \% \mathrm{ECL}+0.2 \% \mathrm{OP})$ had insignificantly higher values, respectively, as compared to the control diet.

The results indicated that level and type of NFA supplementation insignificantly affected all immune response parameters (Table 5). From this table, it can be observed that any level of the dietary treatments surpassed the control for primary immunity response, secondary immunity response, cellular immunity and nearly hematocrit. Concerning type of addition, hens fed ECL had insignificantly higher secondary immunity response, cellular immunity and hematocrit, while, those fed (ECL + OP) mix containing diets had insignificantly higher primary immunity response, hemoglobin, red blood cells and white blood cells (Table 5). In this respect, Ibrahim (2005) reported that orange peel without or with $\mathrm{NaCl}$ and sorrel with $\mathrm{NaCl}$ significantly increased the red blood cells and white blood cells compared to the control group. In case of orange peel, it may be due to the adequate amount of alpha-tocopherol in rabbits blood that simultaneously ingested the highest amounts of the vitamin $\mathrm{C}$. The improvement in immune system in orange peel treatment was agreed with Ding $\boldsymbol{e t}$ al. (2004) who found that orange peel could greatly improve the immune function. The same trend in orange peel may be due to the antioxidant activity. Manthey (2004) showed that, the significant amount of the total antioxidant activity in orange peel was attributable to minoroccurring flavones. Orange peel extracts constituents may counteract enzymatic lipid peroxidation processes (Malterud and Rydland, 2000).

Economical efficiency (EEf): Table 6 showed the economical efficiency (EEf) and the relative economical efficiency (relative EEf) values. Hens fed diet 2 (containing $0.20 \%$ ECL) gave the best economical and relative efficiency values being 1.429 and $110.6 \%$, respectively followed by hens fed diet $7(0.2 \%$ ECL+ $0.4 \%$ OP) $(1.345$ and $104.1 \%$, respectively), diet $6(0.2 \%$ $\mathrm{ECL}+0.2 \% \mathrm{OP})$ then diet $5(0.4 \% \mathrm{OP})$, all of which are superior compared to the control diet without supplementation. Whereas, those fed D8 (0.4\% ECL + $0.2 \% \mathrm{OP}$ ) had the worst corresponding values, being 1.185 and $91.68 \%$, respectively. The relative efficiency varied between -8.32 to $+10.6 \%$ which is of minor importance relative to the other factors of production.

In conclusion, the best performance was seen when $0.20 \%$ ECL or $0.2 \%$ ECL+ $0.4 \%$ OP or $0.2 \%$ ECL+ $0.2 \%$ OP were incorporated as natural feed additives in laying diets as they which gave the best economical and relative efficiency values for egg production.

Fayoum J. Agric. Res. \& Dev., Vol. 21, No. 2, July, 2007 
Table 5

Fayoum J. Agric. Res. \& Dev., Vol. 21, No. 2, July, 2007 
EFFECTS OF USING DRIED EGYPTIAN CLOVER AND ORANGE.. 200

Table 6

Fayoum J. Agric. Res. \& Dev., Vol. 21, No. 2, July, 2007 
REFERENCES

Al-Homaidan, A.A. (2000). Effect of vitamin C addition in water for broilers raised under two different ambient temperatures on growth performance and water consumption. Egypt. Poult. Sci., 20: 327-346.

Allain, C.C. (1974). Clin. Chem., 20: 470.

Anagnostopoulou, M.A.; Kefalas, P.; Kokkalou, E.; Assimopoulou, A.N. and Papageorgiou, V.P. (2005). Analysis of antioxidant compounds in sweet orange peel by HPLC-diode array detection-electrospray ionization mass spectrometry. Biomed Chromatogr.,19:138 - 148.

Association of Official Analytical Chemists, A.O.A.C. (1990). Official methods of analysis. $15^{\text {th }}$ Ed. Published by the AOAC., Washington, D. C., USA.

Atta, A.M.; Abdou, A.M.; Mohamed, F.R. and Goher, N.E. (1998). Immunological variation among commercial broiler strains. Egypt. J. Anim. Prod., 35: 113-124.

Bauer, J.D. (1970). Numerical evaluation of red blood, white blood cells and platelets, part III, Haematology in; Gradwoll, Clinical Laboratory Methods and Diagnoiss, Ed Frankel, S.; Reitman, S. and Somen Wirth, A. C. $7^{\text {th }}$ Ed. C. V. Mosby Co., Saint Louis, USA.

Brahmakshatriya, R.D. and Shrivastava, S.M. (1978). Studied on various products for desirable egg yolk pigmentation. Ind. Vet. J., 55: 788-791.

Carter, T.C. (1968). The hen egg. A mathematical model with three parameters. Br. Poult. Sci., 9: 165 - 171.

Ding, G.; Chen, Z.; Li, W.; Yang, G. and Xu, C.Y. (2004). Studies on effects of grass carp cell immune function by adding orange peels. Chinese J. Yunnan Agric. Univ., Yunnan Agric. Univ., Kunming, China: 19: 727-730.

Dix, M.C. and Taylor, R.L.J. (1996). Differential antibody responses in 6.B maior histocompatbility (B) complex congenic chickens. Poult. Sci., 75: $203-207$.

Donalson, L.M.; Kim, W.K.; Hererra, P.; Woodward, C.L.; Kubena, L.F.; Nisbet, D.J. and Ricke, S.C. (2004 a). Combining a prebiotic with an alfalfa molting diets to increase in vitro fermentation by laying hen cecal bacteria. Poult. Sci., 83:1798. (Abstr.)

Donalson, L.M.; Kim, W.K.; Hererra, P.; Woodward, C.L.; Kubena, L.F.; Nisbet, D.J. and Ricke, S.C. $(2004$ b). The influence of a fructooligosaccharide (FOS) prebiotic with feed substrates on in vitro Salmonella typhimurium growth of laying hen cecal bacteria. Poult. Sci., 83:72. (Abstr.)

Dragsted, L.O.; Young, J.F.; Loft, S.; Sandstrom, B.; Nesaretnam, K. and Packer, L. (2001). Relationship to intervention with antioxidant-rich foods. Biomarkers of oxidative stress and of antioxidative defense Micronutrients-and-health. Molecular Biological-Mechanisms, 272278.

Dumas, B.T. and Biggs, H.G. (1972). In Standard Methods of Clinical Chemistry. Vol 7, Academic Press New York, USA.

Duncan, D.B. (1955). Multiple range and multiple F tests. Biometrics, 11: $1-42$.

Fayoum J. Agric. Res. \& Dev., Vol. 21, No. 2, July, 2007 
EFFECTS OF USING DRIED EGYPTIAN CLOVER AND ORANGE.. 202

Elghaffar, S.K.A. ; Aly, F.M.; Moustafa, A. and Mahmoud, A.Z. (2000). Pathological studies on the rabbit viral hemorrhagic disease (RVHD) with special reference to the use of vitamins $\mathrm{A}, \mathrm{E} \& \mathrm{C}$ as prophylaxis. Assiut-Veterinary-Medical-J., 43: 251-274.

El-Husseiny, O.; Arafa, S.; Abdel-Motagally, Z. and El-Mallah, G. (2000). Response of layer performance to dietary natural pro-vitamin (A) sources. Egypt. Poult. Sci., 20: 703-719.

Forage, A.J. (1979). Utilization of agricultural and food processing wastes containing carbohydrates. Chem. Soc. Revs., 8: 309-314.

Galati, E.M.; Trovato, A.; Kirjavainen, S.; Forestieri, A.M.; Rossitto, A. and Monforte, M.T. (1996). Biological effects of hesperidin, a Citrus flavonoid. (Note III): antihypertensive and diuretic activity in rat. Farmaco, 51: 219-221.

Garcia, J.; Carabano, R.; Perez-Alba, L. and de Blas, J.C. (2000). Effect of fiber source on cecal fermentation and nitrogen recycled through cecotrophy in rabbits. J. Anim. Sci.78: 638-646.

Ghazi, A. (1999). Extraction of beta-carotene from orange peels. Nahrung Aug., 43: 274-281.

Goodwin, J.F. (1970). Clin. Chem., 16: 776-780.

Guclu, B.K.; Iscan, K.M.; Uyanik, F.; Eren, M. and Agca, A.C. (2004). Effect of alfalfa meal in diets of laying quails on performance, egg quality and some serum parameters. Archives of Animal Nutrition, 58, Issue 3, 255-263.

Hashish, S.M.; El-Husseiny, O.M. and Eissa, A.I. (1983). Effect of dietary vitamin A levels on egg production, incidence of blood spots and the intensity of egg yolk color. Ann. Agric. Sci. Moshtohor. Zagazig University, 20: 1.

Hasin, B.M.; Ferdaus, A.J.M.; Islam, M.A.; Uddin, M.J. and Islam, M.S. (2006). Marigold and orange skin as egg yolk color promoting agents. Inter. J. Poult. Sci., 5: 979-987.

Haugh, R.R. (1937). The Haugh unit for measuring egg quality. US Egg Poult. Mag., 43: 552-555.

Howanitz, P.J. and Howantitz, J.H. (1984). In Clinical Diagnosis and Management by laboratory Methods, 168 .

Hsu, C.C.; Jiang, S.; Isemura, M.; Hsu, C.C.; Jiang, S. T.; Chen, Y.Y.; Yen, C.C. and Wong, Y.C. (1999). Effect of ascorbic acid on mouse plasma fibronectin concentration. Nutritional Sci. J., 24: 241-249.

Ibrahim, Sh.A.M. (2005). Effect of some different sources of vitamin C on performance of New Zealand growing rabbit in hot climates. Egypt. Poult. Sci., 25: 845-861.

Khaton, A.; Ali, M.A. and Dingle, J.G. (1999). Comparison of the nutritive value for laying hens of diets containing azolla (Azolla pinata) based on formulation using digestible protein and digestible amino acid. Anim. Feed Sci. Tec., 81: 43-56.

Klita, P.T.; Mathison, G.W.; Fenton, T.W. and Hardin, R.T. (1996). Effects of alfalfa root saponins on digestive function in sheep. J. Anim. Sci., 74: 1144 - 1156.

Kroyer, G. (1986). The antioxidant activity of citrus fruit peels. ZErnahrungswiss, 25: 63-72.

Fayoum J. Agric. Res. \& Dev., Vol. 21, No. 2, July, 2007 
Lehman, H.P. and Henry, J.B. (1984). In Clinical Diagnosis and Management by laboratory Methods, 1431-1438.

Mahfouz, M.M.; Kawano, H. and Kummerow, F.A. (1997). Effect of cholesterol-rich diets with and without added vitamins $\mathrm{E}$ and $\mathrm{C}$ on the severity of atherosclerosis in rabbits. American-J. of Clinic-Nut., 66: 1240-1249.

Malterud, K.E. and Rydland, K.M. (2000). Inhibitors of 15-lipoxygenase from orange peel. J. Agric. Food Chem., 48: 5576-80.

Manthey, J.A. (2004). Fractionation of orange peel phenols in ultrafiltered molasses and mass balance studies of their antioxidant levels. J. Agric. Food Chem., 15:7586-7592.

Mcdowell, L.R.; Lizama, L.C.; Marion, J.E. and Wilcox, C.J. (1990). Utilization of aquatic plants in diets for laying hens. 1-Performance and egg-yolk pigmentation. Poult. Sci., 69: 673-678.

Mtambo, M.M.A.; Mushi, E.J.; Kinabo, L.D.B.; Maeda, M.A.; Chen, Y.; Yen, C.; Wong, Y.; Bosco, A.; Castellini, C. and Dal, B.A. (2000). With vitamin $\mathrm{E}$ the meat of rabbits is improved. Rivista-diConiglicoltura, 37: 38-43.

National Research Council, NRC (1994). Nutrient Requirements of Poultry. $9^{\text {th }}$ revised edition. National Academy Press. Washington, D.C., USA.

Odumosu, A. (1982). Ascorbic acid and cortisol metabolism in hypovitaminosis C guineapigs. Int. J. Vitam. Nutr. Res., 52:176-185.

Ponte, P.I.P.; Mendes, I.; Quaresma, M.; Aguiar, M.N.M.; Lemos, J.P.C.; Ferreira, L.M.A.; Soares, M.A.C.; Alfaia, C.M.; Prates, J.A.M. and Fontes, C.M.G.A. (2004). Cholesterol levels and sensory characteristics of meat from broilers consuming moderate to high levels of alfalfa. Poult. Sci., 83: 810-814.

Reitman, S. and Frankel, S. (1957). Amer. J. Clin. Path., 28: 56.

Rinzler, C.A. (1990). The complete book of herbs, spices and condiments. Facts on file, New York. Oxford.

Sikder, A.C.; Chowdhury, S.D.; Rashid, M.A.; Sarker, A.K. and Das, S.C. (1998). Use of dried carrot meal in laying hen diet for egg yolk pigmentation. Asian Aust. J. Anim. Sci., 11: 239-244.

Skrivanova, V.; Marounek, M.; Skrivan, M. and Knizek, J. (1999). Effect of temperature on growth, feed efficiency and mortality of rabbits. 2nd International Conference on Rabbit Production in Hot Climates. Cahiers-Options-Mediterraneennes., 41: 43-45.

Steel, R.G.D. and Torrie, J.H. (1980). Principles and Procedures of Statistics: A Biometrical Approach $2^{\text {nd }}$ ed. McGraw-Hill Book Co., Inc., New York, USA.

Ting, S.V. and Rouseff, R.L. (1983). Dietary fiber from citrus wastes. Characterisation. ACS Symp. Ser., 205-219.

Tirkey, N.; Pilkhwal, S.; Kuhad, A. and Chopra, K. (2005). Hesperidin, a citrus bioflavonoid, decreases the oxidative stress produced by carbon tetrachloride in rat liver and kidney. BMC Pharmacol., 31:2.

U.S. Feed Grain Council (1994). Quality control system on commodities and finished feeds.

Vuilleumiler, J.P. (1969). The "Roche yolk Color Fan" an instrument for measuring yolk color. Poult. Sci., 48: 767.

Wahlefeld, A.W. (1974). In Methods of Enzymatic Analysis. Vol 5, HU Bergmever, Ed. Academic Press, New York, 1831-1835.

Fayoum J. Agric. Res. \& Dev., Vol. 21, No. 2, July, 2007 
EFFECTS OF USING DRIED EGYPTIAN CLOVER AND ORANGE.. 204

Weichselbaum, P.E. (1946). Am. J. Path., 16: 40.

Well, R.J. (1968). The measurement of certain egg quality: A study of the hens egg. Ed. By T.C. Carter Pub. Oliver and Boyd Edinbrugh pp. 220226 and 235-236.

Wintrobe, M.M. (1965). Clinical Haematology, $4^{\text {th }}$ ed. Philadelphia.]

Yamamoto, Y.; and Glick, B. (1982). A comparison of the immune response between two lines of chickens selected for differences in the weight of the bursa of fabricius. Poult. Sci., 61: 2129 - 2132.

تأثير استخدام البرسيم المصري المجفف وقشر البرتقال كإضافات غذائية طبيعية علي إنتاج البيض

و جودة البيض والاستجابة المناعية للاجاج البياض ليجل

مني سيا رجب وحنان عبد الله حسن

قسم الاواجن - كلية الزراعة - جامعة الفيوم - مصر علب لهن

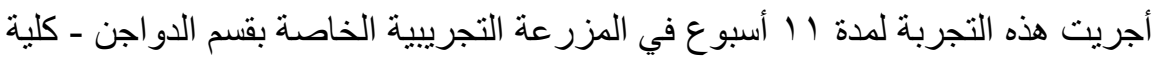

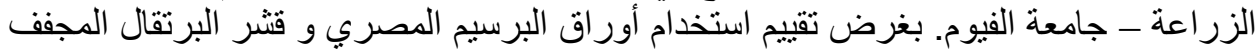

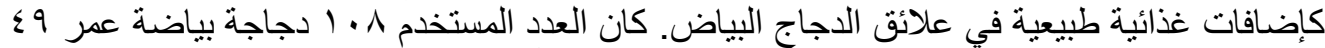

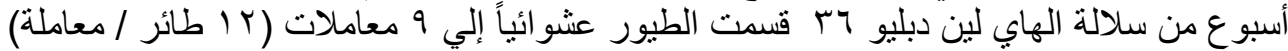

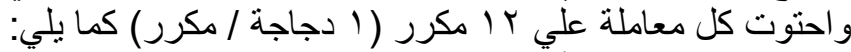
1 - كنترول (العليقة الأساسية).

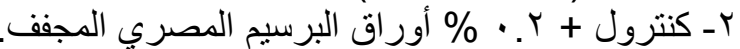

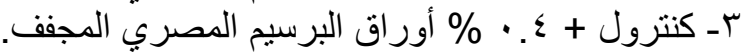

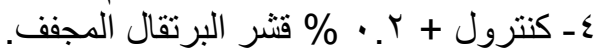

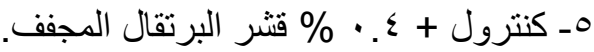

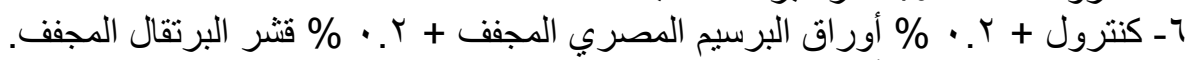

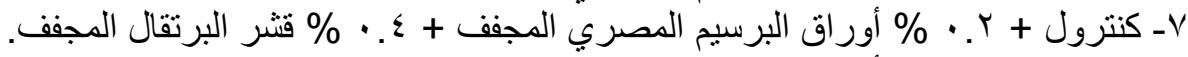

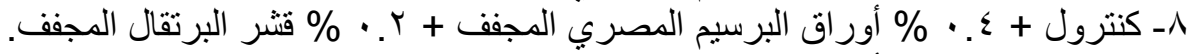

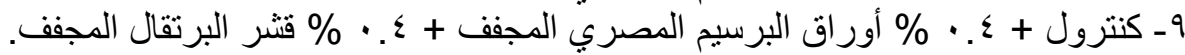

وتتلخص أهم النتائج المتحصل عليها فيما يلي:-

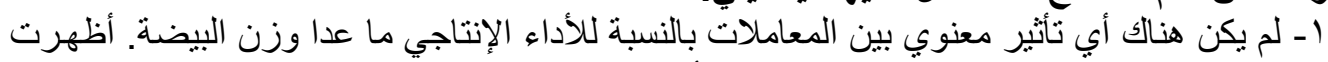

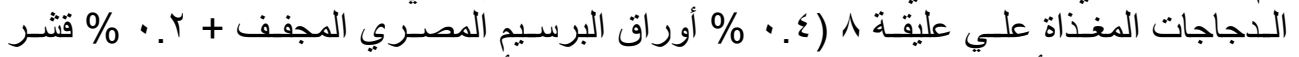

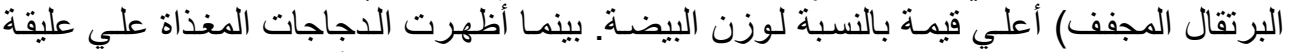

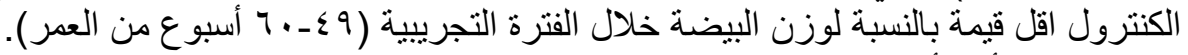

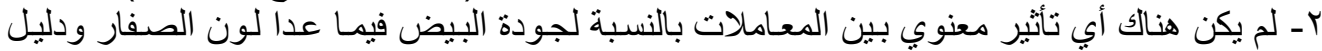

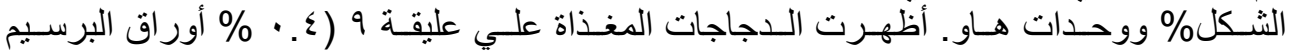

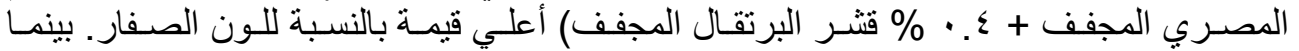

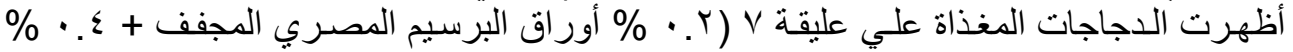

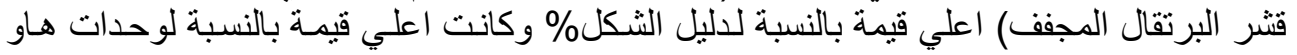
للاجاجات المغذاة علي عليقة الكنترول.

r- كان هناك تأثير معنوي نتيجة للتغذية علي التئية الإضافات الغذائية الطبيعية علي محتوي السيرم من

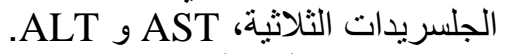

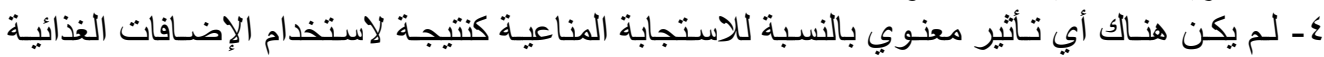
الطبيعية في علائق الدجاج البياض خلائ الفنترة التجريبية.

Fayoum J. Agric. Res. \& Dev., Vol. 21, No. 2, July, 2007 


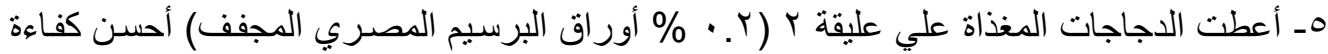

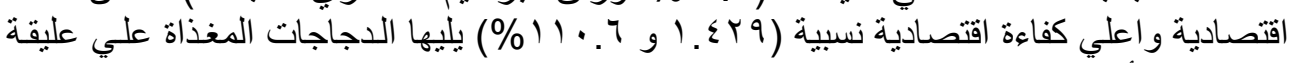

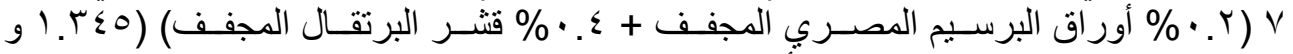

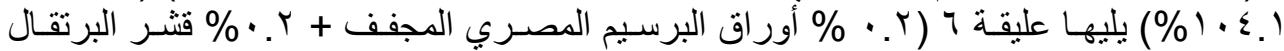

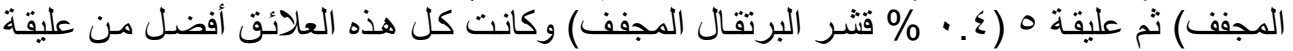

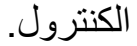

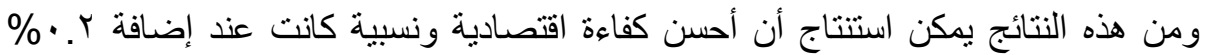

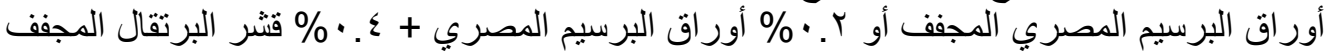

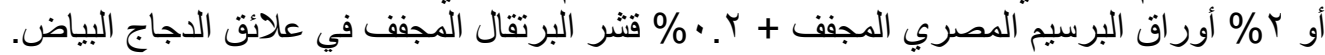

